\title{
Proces realizacji Reformy WŁoskiego systemu UTRZYMANIA DUCHOWIEŃSTWA ZGODNIE Z KONKORDATEM Z 1984 R.
}

\section{Wstęp}

Funkcjonujący dziś we Włoszech system utrzymania katolickiego duchowieństwa, będący konsekwencją reformy zainicjowanej Układem modyfikującym Konkordat Laterański podpisanym w dniu 18 lutego 1984 r. ${ }^{1}$, stanowi jedną z najpoważniejszych, pozytywnie zweryfikowanych przez upływ czasu, prób realizacji kan. 1274 obowiązującego Kodeksu Prawa Kanonicznego (dalej: KPK) ${ }^{2}$. Zgodnie z powołanym przepisem - który nie tylko nie miał swojego odpowiednika w poprzednio obowiązującym Kodeksie pio-benedyktyńskim z 1917 r. ${ }^{3}$, ale definitywnie zerwał z wy-

* Dr hab., prof. KUL, Katolicki Uniwersytet Lubelski Jana Pawła II, Wydział Prawa, Prawa Kanonicznego i Administracji, Katedra Prawa Wyznaniowego, e-mail: pstan@kul.pl, https:/ / orcid.org/0000-0002-2437-8513.

1 Zob. ustawę z 25 marca 1985 r., nr 121. Ratifica ed esecuzione dell'accordo, con protocollo addizionale, firmato a Roma il 18 febbraio 1984, che apporta modificazioni al Concordato lateranense dell'11 febbraio 1929, tra la Repubblica italiana e la Santa Sede, Gazzetta Ufficiale della Repubblica Italiana (dalej: G. U.) nr 85 z 10 kwietnia 1985 r. (dodatek zwykły).

2 Codex Iuris Canonici auctoritate Ioannis Pauli PP. II promuglatus (25.01.1983), Acta Apostolicae Sedis (dalej: AAS) 75(1983), cz. II, s. 1-317.

3 Codex Iuris Canonici Pii X Pontificis Maximi iussu digestus Benedicti Papae XV auctoritate promulgatus (27.05.1917), AAS 9(1917), cz. II, s. 1-593. 
korzystywanym przez wieki i utrzymanym przez ten Kodeks systemem beneficjalnym ${ }^{4}$ -

w poszczególnych diecezjach powinna istnieć specjalna instytucja, gromadząca dobra i ofiary przeznaczone na utrzymanie duchownych, którzy pełnią służbę dla dobra diecezji, zgodnie z postanowieniami kan. 281, chyba że inaczej temu zaradzono 5 .

Doświadczenia związane z realizacją kan. 1274 KPK we włoskich realiach zasługują na uwagę z kilku różnych perspektyw. Pierwszorzędnie istotna, lecz wciąż oczekująca na swoje kompleksowe omówienie w polskojęzycznej literaturze przedmiotu, jest oczywiście sama treść unormowań przyjętych w tamtejszym Kościele partykularnym dla zapewnienia duchownym wynagrodzenia ${ }^{6}$, które - zgodnie z kan. 281 § 1 KPK - byłoby

odpowiednie ich pozycji, z uwzględnieniem zarówno natury ich zadania, jak również okoliczności miejsca i czasu, dzięki któremu mogliby zaspokoić potrzeby własnego życia a także wynagrodzić tych, których pomocy potrzebują ${ }^{7}$.

4 O genezie i wykładni kan. 1274 KPK piszą m.in.: P. Lewandowski, The fund for the suport of the clergy according to the 1983 Code of Canon Law, Biuletyn Stowarzyszenia Kanonistów Polskich 2019, nr 32, s. 119-134; P. Kaleta, Prawne aspekty zarzadzania dobrami kościelnymi, Lublin 2017, s. 53-58; G. Marcuzzi, Il sostentamento del clero nella normativa codiciale latina, w: Il sostentamento del clero. Nella legislazione canonica e concordataria italiana, Città del Vaticano 1993, s. 33-78.

5 Polskie tłumaczenie kanonów za: Codex Iuris Canonici auctoritate Ioannis Pauli PP. II promuglatus. Kodeks Prawa Kanonicznego. Przektad polski zatwierdzony przez Konferencje Episkopatu Polski, Poznań 1984.

6 Na temat założeń i podstawowych rozwiązań składających się na włoski system utrzymania duchowieństwa katolickiego zob. G. Feliciani, Finansowanie instytucji kościelnych i utrzymanie duchowieństwa. Doświadczenia włoskie, w: Systemy finansowania instytucji kościelnych w Europie. Materiaty Międzynarodowej Konferencji. Sandomierz, 13-14 września 1999 r., red. J. Krukowski, Lublin 2000, s. 45-64; P. Stanisz, Konkordatowa reforma systemu finansowania Kościoła we Wtoszech, Premislia Christiana 2014/2015, t. 16, s. 43-44. System ten najpełniej omawia N. Fiorita, Remunerazione e previdenza dei ministri di culto, Milano 2003, s. 61-178.

7 Na temat interpretacji tego unormowania zob. w szczególności: R. Kantor, Odpowiednie wynagrodzenie duchownych w Kodeksie Prawa Kanonicznego z 1983 r. Analiza kan. 281 $\S 1$, Prawo Kanoniczne 2011, nr 3-4, s. 191-222; P. Lewandowski, Troska biskupa diecezjalnego o godziwe utrzymanie duchownych, Kościół i Prawo 2016, nr 1, s. 53-76; J.E. Lynch, The obligations and rights of clerics, w: New Commentary on the Code of Canon Law, red. J.P. Beal, J.A. Coriden, T.J. Green, New York, N.Y.-Mahwah, N.J. 2000, s. 366-369; J. Krukowski, Święci 
Na baczną uwagę zasługuje jednak również obrana we Włoszech droga do przyjęcia tych unormowań, to jest tryb ich opracowywania i uchwalania. Procesy te stanowią bowiem inspirujący przykład lojalnego i efektywnego współdziałania władz państwowych i kościelnych w ustanawianiu przepisów mających znaczenie $w$ obu porządkach prawnych (państwowym i kościelnym), wyraźnie dowartościowując przy tym rolę krajowej Konferencji Biskupów. Z perspektywy polskiej istotne znaczenie posiada ponad to fakt, że w art. 22 ust. 2 Konkordatu między Stolicą Apostolską i Rzecząpospolitą Polską, podpisanego w dniu 28 lipca 1993 r. ${ }^{8}$, podobnie jak w art. 7 ust. 6 włoskiego Konkordatu z 1984 r., wyrażając przekonanie o potrzebie dokonania zmian $w$ unormowaniach dotyczących spraw finansowych instytucji i dóbr kościelnych oraz duchowienstwa, jednolicie - choć przy użyciu różnych formuł - przewidziano współdziałanie przedstawicieli stron $w$ ramach powołanej $w$ tym celu specjalnej komisji. Natomiast art. 27 polskiego Konkordatu, zgodnie z logiką przyjętą na gruncie włoskiego układu z 1984 r., dowartościowuje rolę Konferencji Episkopatu Polski, przyznaje jej nawet w sprawach wymagających „nowych lub dodatkowych rozwiązań” (i pod warunkiem upoważnienia przez Stolicę Apostolską) prawo do podejmowania wiążących uzgodnień z Rządem Rzeczypospolitej Polskiej. Krytyczna analiza trybu realizacji konkordatowej reformy systemu utrzymania katolickiego duchowieństwa we Włoszech (i związanej z tym reformy systemu finansowania Kościoła) może się więc przyczynić do wypracowania właściwego sposobu wciąż oczekiwanej realizacji art. 22 ust. 2 polskiej umowy ze Stolicą Apostolską z 1993 r. ${ }^{9}$

szafarze, czyli duchowni, w: Komentarz do Kodeksu Prawa Kanonicznego, t. 2/1, red. J. Krukowski, Poznań 2005, s. 104-105.

8 Dz. U. z 1998 r. Nr 51, poz. 318.

9 Poza zakresem niniejszych rozważań pozostaje kwestia treści i znaczenia pkt 6 Deklaracji Rządu Rzeczypospolitej Polskiej z dnia 15 kwietnia 1997 r. w celu zapewnienia jasnej wykładni przepisów Konkordatu między Stolicą Apostolską a Rzecząpospolitą Polską, podpisanego w dniu 28 lipca 1993 r. (M. P. z 1998 r. Nr 4, poz. 51). Nie wchodząc w szczegóły tego zagadnienia, należy stwierdzić, że obowiązek układowego regulowania spraw z zakresu wzajemnych stosunków między państwem a Kościołem katolickim (również wówczas, gdy dotyczą one spraw o charakterze majątkowym czy finansowym) wynika z art. 25 ust. 4 Konstytucji Rzeczypospolitej Polskiej (Dz. U. Nr 78, poz. 483 z późn. zm.) analizowanego w powiązaniu z art. 27 Konkordatu. Nie jest w stanie tego zmienić jednostronne oświadczenie rządowe. Prace komisji powołanej zgodnie z art. 22 ust. 2 polskiego Konkordatu powinny więc prowadzić do przyjęcia stosownych aktów 


\section{Treść postanowień konkordatowych}

Pomimo znaczenia przywiązywanego przez Stolicę Apostolską i Rząd Republiki Włoskiej do spraw związanych z funkcjonowaniem kościelnych jednostek organizacyjnych, dobrami kościelnymi oraz systemem finansowania Kościoła i utrzymania duchowieństwa (a raczej właśnie ze względu na to znaczenie), we włoskim Konkordacie z 1984 r. ograniczono się jedynie do sformułowania kilku generalnych zasad dotyczących wymienionych kwestii. Zdawano sobie sprawę ze złożoności tej problematyki oraz z poważnych wątpliwości, które ujawniły się już w trakcie rokowań. Nie chciano więc dodatkowo odwlekać zakończenia prac nad umową, której potrzeba jawiła się jako oczywista i która była przedmiotem negocjacji prowadzonych już od kilkunastu lat ${ }^{10}$. W związku z tym zdecydowano

dwustronnych, podobnie jak to miało miejsce przy realizacji art. 7 ust. 6 włoskiego Konkordatu z 1984 r. Zob. D. Walencik, Finansowanie Kościoła katolickiego w Polsce w świetle art. 22 i 27 konkordatu oraz prac komisji konkordatowych - perspektywa zmian, w: Konkordat: ocena z perspektywy 15 lat obowiazywania, Kraków 2014, s. 26-39; P. Sobczyk, Konstytucyjna zasada konsensualnego określania stosunków między Rzeczapospolita Polską a Kościołem katolickim, Warszawa 2013, s. 299-306; P. Stanisz, Sprawy majątkowe jako element stosunków między państwem a związkami wyznaniowymi, w: Finansowanie kościołów i innych związków wyznaniowych, red. P. Sobczyk, K. Warchałowski, Warszawa 2013, s. 17-32; tenże, Perspektywy zmiany systemu finansowania kościotów i innych związów wyznaniowych w Polsce, Studia z Prawa Wyznaniowego 2009, t. 12, s. 14-15.

10 Formalne, dwustronne prace nad rewizją reżimu konkordatowego zostały podjęte $\mathrm{w}$ pierwszej połowie lat 70. XX w. Jednak potrzebę dokonania takiej rewizji dostrzegano dość powszechnie już w czasie debat dotyczących republikańskiej konstytucji, którą uchwalono 22 grudnia 1947 r. (G. U. nr 298 z 27 grudnia 1947 r.). Zasady tej ustawy zasadniczej przynajmniej w odniesieniu do niektórych kwestii dość wyraźnie kłóciły się bowiem z postanowieniami Konkordatu Laterańskiego. Na pierwsze poważniejsze próby realizacji postulatu modyfikacji reżimu konkordatowego trzeba jednak było czekać ponad dwadzieścia lat (zob. G. Dalla Torre, La revisione del Concordato lateranense. Una vicenda lunga quarant'anni, Iustitia 2004, nr 2-3, s. 145-157). W dniu 7 kwietnia 1971 r. Izba Deputowanych - w ślad za swą wcześniejszą uchwałą z 5 października 1967 r. wzywającą rząd do podjęcia inicjatyw mających na celu reformę reżimu konkordatowego oraz po zakończeniu prac specjalnie utworzonej komisji, której zadaniem było wskazanie postanowień wymagających zmian z perspektywy państwa włoskiego i po przeprowadzeniu odnoszącej się do tego dyskusji parlamentarnej - zaapelowała do rządu o podjęcie rokowań ze Stolicą Apostolską. Negocjacje rozpoczęto w październiku 1976 r. Do końca 1978 r. zaowocowały one trzema kolejnymi projektami nowej umowy. Projekty te każdorazowo poddawane były ocenie Parlamentu, który w grudniu 1978 r. uznał, że istnieją warunki do tego, aby prace nad nowym Konkordatem weszły w fazę finalną. Dalsze rokowania postępowały jednak 
się na powierzenie zadania wypracowania rozwiązań kompleksowo odnoszących się do omawianej materii specjalnie do tego powołanej komisji państwowo-kościelnej. Określając jej zadania, w art. 7 ust. 6 włoskiego Konkordatu z 1984 r. postanowiono wyraźnie, że ma się ona zająć m.in. rewizją finansowych zobowiązań państwa wobec Kościoła, co ze względu na wielkość państwowego zaangażowania w utrzymanie katolickiego duchowieństwa z natury rzeczy oznaczało również obowiązek podjęcia tego zagadnienia. Przyjęto jednocześnie, że opracowane przez komisję normy będą wymagały aprobaty stron Konkordatu. Natomiast w Protokole dodatkowym do Konkordatu (wraz z nim opublikowanym) zobowiązano komisję do zakończenia prac $\mathrm{w}$ terminie 6 miesięcy.

\section{Działalność komisji parytetowej}

Komisja parytetowa, o której mowa w art. 7 ust. 6 włoskiego Konkordatu, została ukonstytuowana już 23 lutego 1984 r. W jej skład weszli wydelegowani przez obie strony eksperci, specjalizujący się w różnych dziedzinach prawa, oraz osoby reprezentujące zainteresowane instytucje państwowe i kościelne. Ze względu na wieloaspektowość zadań powierzonych komisji, zdecydowano się na utworzenie $\mathrm{w}$ jej ramach czterech podkomisji (zajmujących się odpowiednio sprawami związanymi z osobowością prawną i statusem kościelnych jednostek organizacyjnych, strukturami i zadaniami państwowej administracji wyznaniowej, opodatkowaniem podmiotów kościelnych oraz organizacją kościelną i finansowymi obciążeniami państwa na rzecz Kościoła) ${ }^{11}$.

powoli. W latach 1979-1983 przygotowano cztery kolejne projekty opracowywanej umowy (tym razem, w przeciwieństwie do poprzednich, nie poddawano ich osądowi izb parlamentarnych). Natomiast w dniach 25-27 stycznia 1984 r., na podstawie informacji przedstawionej przez Prezesa Rady Ministrów, w Parlamencie przeprowadzono ostatnie dyskusje, zakończone upoważnieniem rządu do zamknięcia rokowań i podpisania umowy, do czego doszło w dniu 18 lutego 1984 r. Zob. G. Dalla Torre, I tempi e le fasi di una lunga trattativa, w: I nuovi accordi concordatari tra Chiesa e Stato in Italia, Bologna-Roma 1985, s. 133-142; F. Margiotta Broglio, Il negoziato per la riforma del Concordato tra Governo e Parlamento, w: Concordato e Costituzione. Gli accordi del 1984 tra Italia e Santa Sede, red. S. Ferrari, Bologna 1985, s. 9-29.

11 Ze strony rządu w skład komisji weszli: Francesco Margiotta Broglio (profesor relacji Państwo - Kościół w Uniwersytecie Florenckim - jako współprzewodniczący), 
Przyjęte przez komisję tempo prac było od początku bardzo intensywne. Już w pierwszych dniach lipca 1984 r. zakończono opracowywanie szczegółowych założeń projektowanej reformy. W prezentującym je dokumencie (Relazione sui principi - „Studium na temat zasad") ${ }^{12}$ W sposób zdecydowany wyrażono intencję zainicjowania głębokiej i kompleksowej reformy rozwiązań dotyczących finansowych zobowiązań państwa wobec Kościoła. Uzasadniając przyjęte stanowisko, odwołano się do nowatorskich unormowań KPK, dotyczących porzucenia systemu beneficjalnego oraz ustanowienia nowych sposobów zagwarantowania utrzymania duchowieństwa. Zwrócono też uwagę na dezaktualizację założeń stojących u podstaw odnoszącego się do tych kwestii prawa państwowego, mającego za przedmiot zwłaszcza system dodatków uzupełniających (supplementi di congrua), które do tej pory wypłacane były katolickim duchownym w celu uzupełnienia uzyskiwanych przez nich dochodów beneficjalnych do poziomu uznawanego za odpowiedni ${ }^{13}$.

Zgodnie $\mathrm{z}$ deklaracjami zawartymi w powoływanym wyżej studium, opracowywane rozwiązania dotyczące finansowania Kościoła miały się opierać na czterech podstawowych zasadach. Pierwszą z nich było dowartościowanie osobistego wkładu poszczególnych wiernych

Carlo Cardia (profesor prawa wyznaniowego w Uniwersytecie w Pizie), Antonio Malintoppi (profesor prawa międzynarodowego w Uniwersytecie „La Sapienza”, którego zastąpił następnie Vincenzo Caianello, przewodniczący sekcji Rady Stanu), Cesare Mirabelli (profesor prawa wyznaniowego w rzymskim Uniwersytecie „Tor Vergata”), Giuglio Tremonti (profesor prawa podatkowego w Uniwersytecie w Pavii), ambasador Bruno Bottai (dyrektor generalny ds. politycznych w Ministerstwie Spraw Zagranicznych) oraz Aldo de Filippo (dyrektor generalny ds. kultów w Ministerstwie Spraw Wewnętrznych). Natomiast ze strony kościelnej komisję współtworzyli: Pio Cipriotti (profesor prawa wyznaniowego w Papieskim Uniwersytecie Laterańskim i Uniwersytecie „La Sapienza”), Giorgio Feliciani (profesor prawa kanonicznego w Uniwersytecie w Pavii), mec. Edoardo Boitani (konsultor Kongregacji ds. Kleru), mec. Mauro Giovannelli, ks. Giovanni Lajolo (przedstawiciel Rady do Spraw Publicznych Kościoła), ks. Tino Marchi (przewodniczący Federacji Stowarzyszeń Duchowieństwa we Włoszech) oraz ks. bp Attilio Nicora (biskup pomocniczy Archidiecezji Mediolańskiej), pełniący funkcję współprzewodniczącego ze strony kościelnej. Zob. G. Feliciani, Introduzione, w: Enti di culto e finanziamento delle confessioni religiose. L'esperienza di un ventennio (1985-2005), red. I. Bolgiani, Bologna 2007, s. 8.

12 Commissione paritetica per gli enti ecclesiastici, Relazione sui principi, Foro italiano 1984, cz. 5, kol. 368-378.

13 O genezie i funkcjonowaniu systemu wspomnianych dodatków uzupełniających piszą m.in.: P. Consorti, La remunerazione del clero. Dal sistema beneficiale agli istituti per il sostentamento, Torino 2000, s. 30-42; G. Feliciani, Finansowanie..., s. 45-48. 
w zagwarantowanie właściwych warunków funkcjonowania wspólnoty kościelnej, do której należą, oraz należyte poszanowanie podejmowanych przez nich decyzji. W katalogu zasad, na których miały się opierać opracowywane rozwiązania, wymieniono następnie promowanie mechanizmów „ułatwionego samofinansowania” (autofinanziamento facilitato) wspólnot religijnych, przypisując istotną rolę instrumentalnemu wsparciu, które miało być udzielane przez administrację publiczną. Jako trzecią wskazano regułę, zgodnie z którą dochody uzyskiwane dzięki planowanym rozwiązaniom mają być wydatkowane na wyraźnie określone cele, w tym zwłaszcza na utrzymanie duchownych. W omawianym katalogu zasad uwzględniono ponadto konieczność wykorzystania - przy zapewnianiu duchownym godnych warunków życia - zarówno mechanizmów wyrównywania konsekwencji zróżnicowanej sytuacji majątkowej instytucji kościelnych w różnych regionach oraz diecezjach, jak i transparentności procesu rozdzielania pozyskiwanych środków ${ }^{14}$.

„Studium na temat zasad" zostało przekazane przedstawicielom obu stron Konkordatu, co umożliwiło m.in. przeprowadzenie nad tym dokumentem debaty parlamentarnej. W jej konsekwencji przyjmowane przez komisję kierunki rozwiązań uzyskały nie tylko aprobatę rządu, ale i pozytywną opinię większości ugrupowań parlamentarnych ${ }^{15}$.

Akceptacja założeń projektowanej reformy przez władze państwowe i kościelne pozwoliła komisji parytetowej na niezakłócone kontynuowanie prac. Dzięki temu już 8 sierpnia 1984 r. w ramach tego gremium udało się osiągnąć porozumienie co do kształtu opracowywanych „Norm dotyczących podmiotów i dóbr kościelnych we Włoszech oraz rewizji zobowiązań finansowych Państwa Włoskiego i jego ingerencji w zarządzanie majątkiem podmiotów kościelnych" (Norme circa gli enti e beni ecclesiastici in Italia e circa la revisione degli impegni finanziari dello Stato Italiano e degli interventi del medesimo nella gestione patrimoniale degli enti ecclesiastici). Dokument ten został przekazany do akceptacji stronom Konkordatu, zgodnie $\mathrm{z}$ jego art. 7 ust. 6 .

14 Zob. F. Margiotta Broglio, Riforma della legislazione concordataria sugli enti e sul patrimonio ecclesiastico: $i$ «principi» della Commissione paritetica Italia - S. Sede, Foro Italiano 1984, cz. 5, kol. 368-369.

15 Tamże, kol. 369. 


\section{Zapewnienie obowiązywania uzgodnionych norm w państwowym i kościelnym porządku prawnym}

Zgodnie z art. 7 ust. 6 włoskiego Konkordatu z 1984 r. unormowania opracowane przez komisję parytetową wymagały aprobaty stron tej umowy międzynarodowej. W związku z tym niektóre z postanowień zostały jeszcze poddane nieznacznym modyfikacjom, natomiast w odniesieniu do innych uzgodniono ich wiążącą wykładnię ${ }^{16}$. Dzięki temu możliwe stało się ostateczne zaakceptowanie ich przez przedstawicieli Stolicy Apostolskiej i Republiki Włoskiej, do czego doszło na mocy protokołu z dnia 15 listopada 1984 r. ${ }^{17}$ Wymiana dokumentów ratyfikacyjnych, odnoszących się zarówno do protokołu z 15 listopada 1984 r., jak i do samego Konkordatu, nastąpiła w dniu 3 czerwca 1985 r. Data ta - zgodnie z art. 13 ust. 1 Konkordatu oraz art. 5 protokołu - stanowiła również dzień wejścia w życie przyjętych w ten sposób dokumentów, traktowanych jako akty prawa międzynarodowego.

Nie ograniczając się do omówionych wyżej skutków, w art. 4 protokołu z 15 listopada 1984 r. przyjęto ponadto, że obie strony wprowadzą uzgodnione normy do własnych porządków prawnych, wydając właściwe tym porządkom akty. Natomiast $\mathrm{w}$ art. 75 aprobowanego protokołem dokumentu postanowiono, że zawarte w nim unormowania wejdą w życie w państwowym i kościelnym porządku prawnym po ich promulgacji we właściwych, oficjalnych organach publikacyjnych.

Już w dniu wymiany dokumentów ratyfikacyjnych kard. Agostino Casaroli, działając na mocy specjalnych uprawnień przyznanych mu przez papieża Jana Pawła II zgodnie z kan. 30 KPK, wydał dekret, na którego treść złożyły się przepisy uzgodnione z przedstawicielami Republiki

16 Zob. Scambio di lettere tra Sua Eminenza Reverendissima il Signor Cardinale Agostino Casaroli, Segretario di Stato, Prefetto del Consiglio per gli Affari Pubblici della Chiesa, e Sua Eccellenza L'Onorevole Signore Bettino Craxi, Presidente del Consiglio dei Ministri della Repubblica Italiana, AAS 77(1985), s. 538-543.

17 Podpisy pod tym dokumentem złożyli: kard. Agostino Casaroli (Sekretarz Stanu Stolicy Apostolskiej i Prefekt Rady do Spraw Publicznych Kościoła) oraz Bettino Craxi (Prezes włoskiej Rady Ministrów). Zob. Protocollo di approvazione delle Norme per la disciplina della materia di cui all'art. 7 n. 6 dell'Accordo tra la Santa Sede e la Repubblica Italiana ache apporta modificazioni al Concordato Lateranense, AAS 77(1985), s. 536-537. 
Włoskiej ${ }^{18}$. Przyjęty w ten sposób akt miał charakter dekretu ogólnego, zgodnie z kan. $29 \mathrm{KPK}^{19}$, stanowiąc źródło kanonicznego prawa partykularnego pochodzącego od najwyższego prawodawcy kościelnego ${ }^{20}$.

Bez kontrowersji nie dokonało się natomiast wprowadzenie norm opracowanych przez komisję parytetową do prawa włoskiego. Jak zauważa się w doktrynie, prawodawca państwowy przystąpił do realizacji stojącego przed nim zadania w sposób wyjątkowo nieuporządkowany i pozbawiony myśli przewodniej, czego efektem jest jednoczesne obowiązywanie dwóch różnych ustaw mających niemal tę samą treść. Prace nad ustawą zawierającą dwustronnie wypracowane regulacje prowadzono bowiem odrębnie od procedur dotyczących zgody na ratyfikację protokołu z 15 listopada 1984 r. Pierwsze ze wspomnianych prac zakończyły się uchwaleniem ustawy nr 222 z dnia 20 maja 1985 r., która od strony formalnej nie przejawia żadnych cech charakterystycznych, wiernie powtarzając przepisy wypracowane przez komisję parytetową i nieznacznie zmodyfikowane na ostatnim etapie prac na mocy uzgodnień dokonanych przez przedstawicieli stron Konkordatu ${ }^{21}$. Natomiast $\mathrm{w}$ trakcie realizacji procedur odnoszących się do protokołu z 15 listopada 1984 r. do ustawy zawierającej zgodę na jego ratyfikację dołączono również „Normy dotyczące podmiotów i dóbr kościelnych we Włoszech oraz rewizji zobowiązań finansowych Państwa Włoskiego i jego ingerencji w zarządzanie majątkiem podmiotów kościelnych" (tym razem dokładnie w tej wersji, która została uzgodniona przez komisję parytetową, chociaż z zastrzeżeniem, że aprobata obejmuje tekst ostatecznie uzgodniony przez strony Konkordatu na ostatnim etapie prac, przy czym odnoszące się do tego listy opublikowano jako załącznik do protokołu) ${ }^{22}$. W konsekwencji należy przyjąć,

18 Agostino Card. Casaroli, Segretario di Stato, Prefetto del Consiglio per gli Affari Pubblici della Chiesa, Decreto (3.06.1985). Norme circa gli enti e beni ecclesiastici in Italia e circa la revisione degli impegni finanziari dello Stato Italiano e degli interventi del medesimo nella gestione patrimoniale degli enti ecclesiastici, AAS 77(1985), s. 547-578.

19 F. Finocchiaro, Diritto ecclesiastico, Bologna 2015, s. 14.

20 G. Feliciani, Il nuovo sistema di sostentamento del clero. Profili canonistici della legge 20.5.1985, n. 222, Aggiornamenti Sociali 1990, nr 1, s. 65

21 Disposizioni sugli enti e beni ecclesiastici in Italia e per il sostentamento del clero cattolico in servizio nelle diocesi, G. U. nr 129 z 3 czerwca 1985 r. (dodatek zwykły).

22 Zob. ustawę z dnia 20 maja 1985 r., nr 206. Ratifica ed esecuzione del protocollo, firmato a Roma il 15 novembre 1984, che approva le norme per la disciplina della materia degli enti e beni ecclesiastici formulate dalla commissione paritetica istituita dall'art. 7, n. 6, dell'accordo, con 
że nawet jeśliby ustawodawca zdecydował się na zmianę lub uchylenie ustawy nr 222, zawarte w niej unormowania będą nadal obowiązywać na podstawie ustawy nr 206, której zmiana lub uchylenie wymaga uprzedniego zastosowania instrumentów właściwych prawu międzynarodowemu publicznemu ${ }^{23}$.

\section{Istota reformy finansowania Kościoła}

Przyjęcie wymienionych wyżej aktów normatywnych oznaczało rezygnację zarówno z systemu beneficjalnego, jak i z wypłacania katolickim duchownym państwowych dodatków uzupełniających. W zamian za to do prawa włoskiego wprowadzono nową instytucję prawną, tj. asygnatę podatkową określaną od jej wysokości $(0,8 \%)$ mianem otto per mille. Jej istotą jest przyznanie podatnikom podatku dochodowego od osób fizycznych prawa decydowania o przeznaczeniu określonej w ten sposób części dochodów uzyskiwanych przez państwo z tej daniny. Środki te - zgodnie z pierwotnym brzmieniem przepisów odnoszących się do omawianej instytucji prawnej - miały być dzielone, zgodnie z wolą podatników, pomiędzy Kościół katolicki i państwo ${ }^{24}$. W uzgodnionych unormowaniach przyjęto, że kwoty odpowiadające odsetkowi podatników, którzy nie skorzystali z prawa udziału w określaniu przeznaczenia środków z 0,8\% podatku (udział ten jest bowiem prawem, a nie obowiązkiem), zostaną podzielone zgodnie z proporcjami wyznaczonymi przez podatników, którzy

protocollo addizionale, del 18 febbraio 1984 che ha apportato modificazioni al Concordato lateranense del 1929 tra lo Stato italiano e la Santa Sede, G. U. nr 123 z 27 maja 1985 r. (dodatek zwykły).

${ }^{23}$ F. Finocchiaro, Diritto..., s. 13-14. Odmiennego zdania jest S. Berlingò. Utrzymuje on, że uchwalenie ustawy nr 222 było realizacją zobowiązania ustanowionego w ustawie nr 206, a w związku z tym jedynie ta pierwsza może być traktowana jako źródło prawa krajowego dotyczącego podmiotów i dóbr kościelnych oraz finansowania Kościoła katolickiego i utrzymania jego duchownych. Zob. S. Berlingò, Fonti del diritto ecclesiastico, w: S. Berlingò, G. Casuscelli, S. Domianello, Le fonti e i principi del diritto ecclesiastico, Torino 2000, s. 29.

24 Należy jednak podkreślić, że od początku zakładano stopniowe rozszerzanie omawianych rozwiązań na inne związki wyznaniowe i zadanie to wkrótce zostało podjęte. $\mathrm{Na}$ temat realizacji procesu, w którego konsekwencji z omawianych rozwiązań korzysta dziś we Włoszech kilkanaście związków wyznaniowych zob. P. Stanisz, Porozumienia w sprawie regulacji stosunków między państwem i niekatolickimi związkami wyznaniowymi we włoskim porządku prawnym, Lublin 2007, s. 253-262. 
w tej procedurze wzięli udział ${ }^{25}$. Natomiast wśród celów, na jakie Kościół może wydatkować uzyskiwane w ten sposób dochody, wskazano m.in. utrzymanie duchownych ${ }^{26}$.

Drugim rozwiązaniem, które w konsekwencji omawianej reformy zostało wprowadzone do przepisów o podatku dochodowym od osób fizycznych, była ulga z tytułu darowizn składanych na rzecz nowoutworzonego Centralnego Instytutu do Spraw Utrzymania Duchowieństwa (Istituto Centrale per il sostentamento del clero), którego nazwa właściwie informuje o nadanych mu celach. Górną granicę takich odliczeń ustalono na poziomie $2 \mathrm{mln}$ lirów $\mathrm{w}$ roku ${ }^{27}$.

$\mathrm{W}$ omawianych przepisach zdecydowano ponadto o utworzeniu diecezjalnych (lub - zgodnie z decyzjami zainteresowanych biskupów - międzydiecezjalnych) instytutów do spraw utrzymania duchowieństwa. Na te instytuty nałożono obowiązek materialnego zabezpieczenia duchownych, pozostających w służbie diecezji, przenosząc na nie własność dotychczasowych majątków beneficjalnych, które służyły uzyskiwaniu dochodów. Jednocześnie postanowiono, że środki wypracowywane przez te instytuty dzięki zarządzaniu majątkami pobeneficjalnymi będą $\mathrm{w}$ razie potrzeby uzupełniane przez Instytut Centralny dysponujący nie tylko darowiznami składanymi przez podatników, ale i - zgodnie z decyzjami

25 Włoski podatnik nie decyduje więc o przeznaczeniu 0,8\% płaconego przez siebie podatku dochodowego od osób fizycznych. Uczestniczy raczej - na zasadzie swego rodzaju głosowania - w określeniu proporcji, według których ma zostać podzielona całość wpływów z 0,8\% tej daniny. Zob. G. Vegas, L'otto per mille a vent'anni dalla revisione del Concordato lateranense, Quaderni di Diritto e Politica Ecclesiastica 2004, nr 1, s. 189; G. Feliciani, L'Applicazione della legge 20 maggio 1985, n. 222. Gli esiti di una ricerca, Diritto Ecclesiastico 2006, cz. 1, z. 3-4, s. 460; M. Ventura, Religion and Law in Italy, Alphen aan den Rijn 2013, s. 183.

26 Oprócz tego postanowiono, że środki uzyskiwane przez Kościół z tego źródła mogą być wydatkowane na potrzeby kultu oraz na interwencje charytatywne na rzecz ludności Włoch lub krajów tzw. Trzeciego Świata. Natomiast określając katalog celów wiążących państwo przy wydatkowaniu kwot pochodzących z otto per mille, wyliczono zwalczanie głodu w świecie, usuwanie skutków klęsk żywiołowych, pomoc uchodźcom oraz konserwację dóbr kultury. Zob. H. Misztal, P. Stanisz, Wtoski model finansowania związków wyznaniowych, w: Pro bono Reipublicae. Księga Jubileuszowa Profesora Michała Pietrzaka, red. P. Borecki, A. Czohara, T.J. Zieliński, Warszawa 2009, s. 350-351; S. Ferrari, Państwo i Kościót we Włoszech, w: Państwo i Kościót w krajach Unii Europejskiej, red. G. Robbers, tłum. J. Łopatowska-Rynkowska, M. Rynkowski, Wrocław 2007, s. 400.

27 Po przyjęciu we Włoszech waluty europejskiej jest to 1032,91 euro. Zob. H. Misztal, P. Stanisz, Wtoski model..., s. 344. 
włoskiej Konferencji Biskupów - częścią wpływów z opisanego wyżej mechanizmu asygnaty podatkowej ${ }^{28}$.

\section{Rola Konferencji Biskupów Włoch w procesie realizacji reformy}

Ostatnim etapem procesu realizacji reformy systemu finansowania Kościoła katolickiego i utrzymania jego duchowieństwa we Włoszech było podjęcie przez włoską Konferencję Biskupów serii uchwał konkretyzujących normy wypracowane przez komisję parytetową i zaaprobowane na mocy protokołu z 15 listopada $1984 \mathrm{r}$. Zgodnie z tymi regulacjami zdecydowano się bowiem na utworzenie jednolitego systemu utrzymania katolickiego duchowieństwa w całych Włoszech. W związku z tym najważniejsze zadania związane z nadawaniem kształtu omawianemu systemowi powierzono instytucji, do której należą wszyscy włoscy biskupi ${ }^{29}$.

Przed Konferencją Biskupów postawiono w szczególności zadanie uchwalenia przepisów określających treść statutów diecezjalnych (międzydiecezjalnych) instytutów do spraw utrzymania duchowieństwa, określenie wysokości uposażenia zapewniającego duchownym odpowiednie i godne utrzymanie, określenie form zaangażowania stanowiącego spełnianie posługi na rzecz diecezji zgodnie z kan. 1274 § 1 KPK, ustanowienie sposobów szybkiego rozstrzygania sporów dotyczących decyzji podejmowanych przez instytuty do spraw utrzymania duchowieństwa oraz określenie części ewentualnych nadwyżek budżetowych instytutów diecezjalnych lub międzydiecezjalnych, które to nadwyżki powinny być odprowadzone do Centralnego Instytutu do spraw Utrzymania Duchowieństwa. Ponadto włoska Konferencja Biskupów została ogólnie wskazana jako władza kościelna, do której należy wydawanie kanonicznych przepisów wykonawczych do norm zaaprobowanych przez przedstawicieli państwa włoskiego i Stolicy Apostolskiej ${ }^{30}$.

28 Zob. P. Consorti, La remunerazione..., s. 53-70; P. Stanisz, Konkordatowa reforma..., s. $40-41$.

29 Szczególną odpowiedzialność i wyjątkową rolę Konferencji Biskupów Włoch w procesie realizacji omawianej reformy podkreśla G. Feliciani, Gli Istituti per il sostentamento del clero nella nuova normativa della CEI, Aggiornamenti Sociali 1985, nr 11, s. 687-696; tenże, Il nuovo sistema..., s. 66.

${ }^{30}$ G. Feliciani, Gli Istituti..., s. 687-696 


\section{Uporządkowanie kościelnych spraw majątkowych}

Prace odnoszące się do praktycznej realizacji reformy systemu utrzymania duchowieństwa $\mathrm{w}$ ramach kościelnego porządku prawnego zostały podjęte wkrótce po promulgacji KPK z 1983 r. Przy Sekretariacie Generalnym włoskiej Konferencji Biskupów zaczął wówczas działać specjalnie w tym celu powołany zespół roboczy. Na początku 1985 r. został on przekształcony w formalnie ustanowiony Komitet do spraw Utrzymania Duchownych (Comitato per il sostentamento del Clero). Wśród zadań postawionych przed tym komitetem przez Przewodniczącego Konferencji Biskupów znalazło się przede wszystkim opracowanie projektów unormowań wykonujących normy przyjęte protokołem z 15 listopada 1984 r. w kanonicznym porządku prawnym ${ }^{31}$.

Dzięki pracy Komitetu do spraw Utrzymania Duchownych, po upływie zaledwie kilku tygodni od wymiany dokumentów ratyfikacyjnych dotyczących protokołu z 15 listopada 1984 r., możliwe stało się podjęcie przez włoską Konferencję Biskupów pierwszych wiążących decyzji. Dotyczyły one przyjęcia statutu Centralnego Instytutu do spraw Utrzymania Duchowieństwa, modelowych statutów instytutów diecezjalnych i międzydiecezjalnych oraz zasad wyboru przedstawicieli duchowieństwa do rad zarządzających i komisji rewizyjnych. Dokumenty te zostały w kilku fazach poddane ocenom członków Konferencji Biskupów (przedyskutowano je m.in. na forum Zebrania Plenarnego), a następnie - na mocy specjalnych uprawnień przyznanych przez Stolicę Apostolską w związku z koniecznością realizacji zobowiązań wynikających z nowych unormowań - zostały zaaprobowane przez Przewodniczącego Konferencji Biskupów Włoch dekretami z 20 lipca 1985 r. (które po kolejnych dwóch tygodniach uzyskały recognitio Stolicy Apostolskiej) ${ }^{32}$. Jak zasadnie zwraca się

31 Przewodniczącym Komitetu został ks. bp Attilio Nicora. Zob. Anastasio A. Card. Ballestrero, Presidente della Conferenza Episcopale Italiana, Decreto (22.02.1985; Prot. n. 162/85; Costituzione del Comitato per il sostentamento del clero), Notiziario CEI (dalej: NCEI) 1985, nr 2, s. 26-28.

32 Zob. Ugo Card. Poletti, Vicario Generale di Sua Santità, Presidente della Conferenza Episcopale Italiana, Decreto (20.07.1985; Prot. n. 610/85/I), NCEI 1985, nr 12, s. 407-408; Ugo Card. Poletti, Vicario Generale di Sua Santità, Presidente della Conferenza Episcopale Italiana, Decreto (20.07.1985; Prot. n. 610/85/II), NCEI 1985, nr 12, s. 417; Ugo Card. Poletti, Vicario Generale di Sua Santità, Presidente della Conferenza Episcopale Italiana, Decreto (20.07.1985; Prot. n. 610/85/III), NCEI 1985, nr 12, s. 429-430. 
na to uwagę $\mathrm{w}$ literaturze przedmiotu, przyjęto więc rozwiązanie, które nie odpowiadało normom KPK. Zgodnie z logiką unormowań kodeksowych tego rodzaju decyzje powinny być bowiem podejmowane kolegialnie (zob. kan. $455 \S 2 \mathrm{KPK})^{33}$.

Centralny Instytut do spraw Utrzymania Duchowieństwa został kanonicznie erygowany w dniu 23 października 1985 r. ${ }^{34}$ Jednocześnie ustanowiono jego Radę Zarządzającą (Consiglio di Amministrazione) i Komisję Rewizyjną (Collegio dei Revisori dei Conti) ${ }^{35}$. Natomiast do uznania jego osobowości cywilnoprawnej doszło na podstawie rozporządzenia Ministra Spraw Wewnętrznych z dnia 19 listopada 1985 r. ${ }^{36}$ Przed końcem 1985 r. zakończono również proces kanonicznego erygowania poszczególnych instytutów diecezjalnych i międzydiecezjalnych, dzięki czemu już 20 grudnia tego roku Minister Spraw Wewnętrznych wydał całą serię rozporządzeń w sprawie uznania ich za kościelne osoby prawne na gruncie prawa cywilnego (enti ecclesiastici civilmente riconosciuti) oraz zaaprobowania statutów nadanych im przez władze kościelne. W aktach tych, jednolicie w stosunku do wszystkich 219 instytutów (spośród których niewiele ponad $1 / 4$ stanowiły instytuty międzydiecezjalne), znalazły się ponadto przepisy dotyczące zaaprobowania statutów nadanych tym podmiotom przez władze kościelne ${ }^{37}$.

Tworzeniu wskazanych wyżej instytutów towarzyszyło dokonujące się ex lege wygaszanie beneficjów kościelnych, których wykazy - ze względu na postulat pewności prawa - uwzględniane były w rozporządzeniach

33 Dostrzegając ten fakt, G. Feliciani docenia jednak zakres przeprowadzonych konsultacji, który znacząco wykroczył poza zalecenia przekazane w tej sprawie przez Stolicę Apostolską przewodniczącemu włoskiej Konferencji Biskupów. G. Feliciani, Gli Istituti..., s. 690-691.

${ }^{34}$ Ugo Card. Poletti, Vicario Generale di Sua Santità, Presidente della Conferenza Episcopale Italiana, Decreto (23.10.1985). Erezione in persona giuridica canonica dell'I.C.S.C., NCEI 1985, nr 14, s. 568-569.

35 Ugo Card. Poletti, Vicario Generale di Sua Santità, Presidente della Conferenza Episcopale Italiana, Decreto (23.10.1985). Nomina degli Amministratori e dei Revisori dei Conti dell'I.C.S.C., NCEI 1985, nr 14, s. 569-570.

36 Conferimento della qualifica di ente ecclesiastico civilmente riconosciuto all'Istituto centrale per il sostentamento del clero, in Roma, G. U. z 23 listopada 1985, nr 276.

37 Conferimento della qualifica di ente ecclesiastico civilmente riconosiuto a duecentodiciannove istituti diocesani (I.D.S.C.) e interdiocesani (I.I.S.C.) per il sostentamento del clero, agli sensi degli articoli 22 e 28 della legge 20 maggio 1985, n. 222, G. U. z 7 stycznia 1986 r., nr 4 (dodatek zwykły). 
ministerialnych w oparciu o dokumentację przekazaną przez właściwe władze kościelne. Związane z tym było - również dokonujące się z mocy samego prawa - przeniesienie dotychczasowych majątków beneficjalnych na właściwe miejscowo instytuty do spraw utrzymania duchowieństwa i wygaszenie praw przysługujących do tej pory tytulariuszom beneficjów. Z dniem 1 stycznia 1987 r. los beneficjów podzielił również Fundusz na cele Kultu i kilka innych mniejszych agend służących uprzednio podobnym celom. Utworzony został natomiast Fundusz Budowli Służących Kultowi (Fondo edifici di culto), któremu przypisano zadania związane z konserwacją, restaurowaniem i waloryzacją należących do niego nieruchomości sakralnych, przenosząc na niego patrymonium Funduszu na cele Kultu oraz likwidowanych agend. Aby zapewnić Kościołowi choćby minimum czasu potrzebnego na realizację reformy $\mathrm{w}$ ramach jego własnych struktur, przyjęto ponadto, że do 31 grudnia 1986 r. supplementi di congrua będą wypłacane duchownym na dotychczasowych zasadach, natomiast w późniejszych latach, do 31 grudnia 1989 r., kwotę równą dotychczasowym wypłatom na te cele (corocznie powiększaną o 5\%) państwo będzie przekazywać Konferencji Biskupów, która samodzielnie zdecyduje o jej rozdzieleniu pomiędzy duchownych. Datę pełnego uruchomienia nowego systemu wyznaczono na 1 stycznia $1990 \mathrm{r}^{38}$

Domykając proces porządkowania spraw majątkowych w związku z reformą struktur kościelnych, w odpowiedni majątek nieruchomy wyposażono również diecezje i parafie. Na mocy przepisów z 1985 r. uzyskały one bowiem osobowość prawną (z czym wiązało się pozbawienie osobowości prawnej kościołów parafialnych i katedralnych). Na podstawie decyzji podejmowanych przez właściwych miejscowo biskupów na parafie i diecezje, a także na utrzymane kapituły, przenoszono następnie własność tych nieruchomości pobeneficjalnych, które nie służyły osiąganiu dochodu (dotyczyło to zwłaszcza takich nieruchomości jak budynki sakralne, siedziby biskupów, plebanie czy nieruchomości służące celom duszpasterskim, edukacyjnych i charytatywnym) $)^{39}$.

38 Zob. P. Consorti, La remunerazione..., s. 47-48.

39 Zob. Conferenza Episcopale Italiana, Delibera n. 50 (con allegato). Criteri per l'individuazione e l'assegnazione a diocesi, parrocchie e capitoli non soppressi di beni non redditizi appartenenti agli Istituti diocesani per il sostentamento del clero, NCEI 1986, nr 10, s. 292-299. 


\section{Określenie zasad dotyczących uposażeń należnych duchownym}

Kolejne istotne decyzje dotyczące realizacji omawianej reformy w kanonicznym porządku prawnym zostały podjęte na mocy uchwał przyjętych przez Konferencję Biskupów Włoch na posiedzeniach plenarnych w lutym i maju 1986 r. Dotyczyły one kolejno: kryteriów decydujących o wysokości uposażenia gwarantowanego duchownym pełniącym posługę na rzecz diecezji (uchwała nr 43 ) ${ }^{40}$, dochodów wliczanych do tego uposażenia (uchwała nr 44) ${ }^{41}$, określenia duchownych pełniących posługę na rzecz diecezji (uchwała $n r$ 45) ${ }^{42}$ i samej posługi na rzecz diecezji (uchwała $\left.n r 46\right)^{43}$, zasad ustalania wysokości uposażenia należnego duchownym od podmiotów kościelnych, na rzecz których pełnią posługę (uchwała nr 47) ${ }^{44}$, określenia duchownych mających prawo do uposażenia w latach 1987-1989 (uchwała nr 48) ${ }^{45}$, udzielenia kompetencji Zgromadzeniu Przewodniczących Regionalnych Konferencji Biskupów oraz Prezydium Konferencji Biskupów Włoch do przyjęcia określonych przepisów wykonawczych (uchwała nr 49) ${ }^{46}$ oraz ustanowienia organów do rozstrzygania ewentualnych sporów pomiędzy księżmi i instytutami do spraw utrzymania duchowieństwa (uchwały nr 51 i nr 52) ${ }^{47}$. Po uzyskaniu recognitio Stolicy

40 Conferenza Episcopale Italiana, Delibera n. 43. Criteri per la determinazione della remunerazione dovuta ai sacerdoti che svolgono servizio in favore della diocesi, NCEI 1986, nr 10, s. 280-281.

${ }^{41}$ Conferenza Episcopale Italiana, Delibera n. 44. Proventi derivanti dall'esercizio del ministero da computare ai fini della determinazione della remunerazione, NCEI 1986, nr 10, s. 281-283.

42 Conferenza Episcopale Italiana, Delibera n. 45. Individuazione dei sacerdoti che svolgono servizio in favore della diocesi, NCEI 1986, nr 10, s. 283-285.

43 Conferenza Episcopale Italiana, Delibera n. 46. Determinazione del servizio svolto in favore della diocesi, NCEI 1986, nr 10, s. 285-286.

${ }_{44}$ Conferenza Episcopale Italiana, Delibera n. 47. Criteri per la determinazione della remunerazione dovuta dagli enti ecclesiastici ai sacerdoti del cui ministero si avvalgono, NCEI 1986, nr 10, s. 286-289.

45 Conferenza Episcopale Italiana, Delibera n. 48. Individuazione dei sacerdoti aventi diritto alla remunerazione negli anni 1987, 1988 e 1989, NCEI 1986, nr 10, s. 289-290.

46 Conferenza Episcopale Italiana, Delibera n. 49. Competenza della Riunione dei Presidenti delle Conferenze Episcopali Regionali e della Presidenza della Conferenza Episcopale Italiana per ulteriori determinazioni, NCEI 1986, nr 10, s. 291.

47 Conferenza Episcopale Italiana, Delibera n. 51. Costituzione dell'organo per la composizione di eventuali controversie tra sacerdoti e istituti diocesani per il sostentamento del clero, NCEI 1986, nr 10, s. 299-301; Delibera n. 52. Costituzione dell'organo di composizione di eventuali controversie tra sacerdoti e istituti interdiocesani per il sostentamento del clero, NCEI 1986, nr 10, s. 302-304. 
Apostolskiej, wymaganego na mocy kan. 455 § 2 KPK oraz art. 17 § 3 obowiązującego wówczas Statutu Konferencji Biskupów Włoch ${ }^{48}$, wszystkie te uchwały zostały opublikowane dekretem Przewodniczącego tej Konferencji z 30 grudnia 1986 r. ${ }^{49}$ Do tak ukształtowanego zespołu unormowań w kolejnych latach wprowadzano jeszcze liczne poprawki i uzupełnienia, nie tylko nowelizując akty uchwalone uprzednio ${ }^{50}$, ale i przyjmując nowe ${ }^{51}$. Proces kształtowania i stabilizowania kompleksu unormowań partykularnego prawa kanonicznego dotyczących systemu utrzymania duchownych można uznać za symbolicznie zakończony przez przyjęcie uchwały nr 58 z 1991 r. Stanowi ona swego rodzaju tekst jednolity przepisów obowiązujących już na podstawie poprzednich uchwał (przy nadaniu poszczególnym przepisom nowych oznaczeń i pominięciu unormowań, których zastosowanie odnosiło się jedynie do minionego już okresu) ${ }^{52}$.

48 Zob. Il nuovo Statuto della Conferenza Episcopale Italiana, NCEI 1985, nr 3, s. 63-87.

49 Ugo Card. Poletti, Vicario Generale di Sua Santità per la Città di Roma e Distretto, Presidente della Conferenza Episcopale Italiana, Decreto (30.12.1986; Prot. N. 1603/86), NCEI 1986, nr 10, s. 279.

50 Zob. Conferenza Episcopale Italiana, Delibera n. 43 - modifica, integrazione, NCEI 1987, nr 10, s. 276; Delibera n. 44 - integrazione, NCEI 1987, nr 10, s. 277; Delibera n. 47 - modifica, NCEI 1987, nr 10, s. 277; Delibera $n .45$ - abrogazione della lettera c) e inserimento di un nuovo comma, integrazione della lettera d), integrazione della lettera e), integrazione alla delibera 45, NCEI 1988, nr 9, s. 218-220; Delibera $n .47$ - integrazione, NCEI 1988, nr 9, s. 220; Delibera n. 53 - modifica, NCEI 1988, nr 9, s. 221; Delibera n. 54 - modifica, NCEI 1988, nr 9, s. 221-222; Delibera $n .43$ - modifica, integrazione, NCEI 1990, nr 8, s. 208; Delibera n. 47-modifica, NCEI 1990, nr 8, s. 208-210; Delibera n. 49 - modifica, NCEI 1990, nr 8, s. 210; Delibera n. 51 - modifica, NCEI 1990, nr 8, s. 210-211; Delibera n. 52 - modifica, NCEI 1990, nr 8, s. 211-212.

51 Zob. Conferenza Episcopale Italiana, Delibera n. 53. Estensione del nuovo sistema di sostentamento a tutti i sacerdoti che svolgono servizio in favore della diocesi, NCEI 1987, nr 10, s. 278; Delibera n. 54. Avvio delle funzioni previdenziali integrative e autonome in favore del clero italiano, NCEI 1987, nr 10, s. 279-280; Delibera n. 55. Interventi per assicurare la corretta attuazione delle delibere della CEI in materia di sostentamento del clero, NCEI 1987, nr 10, s. 280-281; Delibera n. 57. Definizione dei criteri e delle procedure per la ripartizione e l'assegnazione della somma destinata alla Chiesa cattolica ex art. 47 delle Norme sugli enti e i beni ecclesiastici (c.d. 8 per mille), NCEI 1988, nr 8, s. 212-213.

52 Conferenza Episcopale Italiana, Delibera n. 58. Testo unico delle disposizioni di attuazione delle norme relative al sostentamento del clero che svolge servizio in favore delle diocesi, NCEI 1991, nr 6, s. 147-158. Ze względu na zakres formalnych ingerencji w treść dotychczas obowiązujących przepisów również w tym przypadku zwrócono się o recognitio Stolicy Apostolskiej (zob. NCEI 1991, nr 6, s. 145). Przyjęcie uchwały nr 58 nie oznaczało oczywiście zamknięcia możliwości dalszego zmieniania kanonicznych unormowań dotyczących system utrzymania duchownych we Włoszech. W kolejnych latach ustalony 
Możliwość faktycznego stosowania nowych rozwiązań wymagała ponadto podjęcia określonych decyzji wykonawczych. W związku z treścią uchwały włoskiej Konferencji Biskupów nr 49 z 1986 r. istotną rolę w tym procesie odegrało Zgromadzenie Przewodniczących Regionalnych Konferencji Biskupów (Riunione dei Presidenti delle Conferenze Episcopali Regionali) oraz Prezydium Konferencji Biskupów Włoch. Decyzja o powierzeniu tym gremiom kompetencji prawodawczych musi być rozpatrywana w kategoriach odstępstwa od zasad określonych w kan. 455 § 2 KPK, zgodnie z którym wydawane przez Konferencję Biskupów dekrety ogólne powinny być przyjmowane przez Zgromadzenie Plenarne. Trzeba się też jednak zgodzić z opinią, że zastosowanie tego odstępstwa posiadało pełne uzasadnienie w konieczności podjęcia wielu skomplikowanych decyzji w krótkim czasie, co dla Zgromadzenia Plenarnego Konferencji Biskupów Włoch - zbierającego się jedynie raz lub dwa razy do roku i liczącego ok. 250 członków - byłoby w praktyce niemożliwe ${ }^{53}$.

Na podstawie przekazanych upoważnień w dniu 10 czerwca $1986 \mathrm{r}$. Zgromadzenie Przewodniczących Regionalnych Konferencji Biskupów skonkretyzowało szereg ogólnych postanowień przyjętych przez Konferencję Biskupów Włoch (przypisując m.in. wartości punktowe do poszczególnych okoliczności określonych w uchwale nr 43). Decyzje te

w niej reżim prawny był wielokrotnie modyfikowany. Zob. Modifica dell'art. 3 della Delibera n. 58, NCEI 1993, nr 8, s. 270-271; Integrazione della delibera n. 58. Inserimento nel sistema corsivo del sostentamento del clero dei sacerdoti stranieri che svolgono il ministero a favore dei loro connazionali imigrati in Italia, NCEI 1999, $\mathrm{nr} 3, \mathrm{~s} .88$; Delibera n. 61. Definizione delle iniziative promozionali, NCEI 1999, nr 3, s. 96; Integrazione della delibera $n$. 58. Onere gravante sulla parrocchia per il sostentamento del clero addetto, NCEI 1999, nr 3, s. 97; Statuti degli Istituti per il sostentamento del clero - modifica, NCEI 1999, nr 3, s. 98-99; Delibera n. 62. Disposizioni circa taluni aspetti della gestione degli Istituti diocesani, NCEI 1999, nr 3, s. 100-101; Integrazione della delibera n. 58. Inserimento dei sacerdoti "Fidei donum" nel Sistema del sostentamento del clero, NCEI 2000, nr 7, s. 212; Delibera n. 63. Provvidenze economiche in favore dei sacerdoti che hanno abbandonato l'esercizio del ministero, NCEI 2000, nr 7, s. 213-214; Inserimento dei sacerdoti "Fidei donum" nel Sistema del sostentamento del clero [modifica], NCEI 2001, nr 6, s. 189-190; Assegnazione di un contributo alle diocesi che accolgono presbiteri stranieri in regime di convenzione, NCEI 2003, nr 7, s. 224-238; Modifica della delibera n. 58 e determinazione in materia di previdenza integrativa, NCEI 2006, nr 8, s. 205; Modifica della delibera $n .58$ in materia di sostentamento del clero, NCEI 2007, nr 5-6, s. 184; Modifiche della delibera $n$. 58 in materia di sostentamento del clero e determinazioni conseguenti, NCEI 2009, nr 5, s. 253-258.

${ }^{53}$ G. Feliciani, Il nuovo sistema..., s. 67. 
uzyskały wymaganą aprobatę Prezydium Konferencji Biskupów Włoch i zostały opublikowane przez Komitet do Spraw Utrzymania Duchowieństwa ${ }^{54}$.

Charakteryzując $\mathrm{w}$ sposób generalny treść unormowań ustanowionych przez włoską Konferencję Biskupów, należy przede wszystkim zwrócić uwagę, że przyjmując je, wyraźnie kierowano się dążeniem do jednoczesnej realizacji trzech idei. Pierwszą $\mathrm{z}$ nich było przekonanie o fundamentalnej równości wszystkich duchownych. Drugą ideą przewodnią było przekonanie o potrzebie premiowania kapłańskiego stażu. Natomiast trzecią było dążenie do zrekompensowania nadzwyczajnego zaangażowania pastoralnego, wiążącego się z powierzonym urzędem lub zadaniami ${ }^{55}$, do czego trzeba dodać ideę wyjścia naprzeciw niektórym szczególnym sytuacjom wymagającym ekonomicznej interwencji ${ }^{56}$. Realizując te idee, ustanowiono dość skomplikowany system, w ramach którego sytuację życiową i pastoralne zaangażowanie poszczególnych duchownych, z uwzględnieniem ich równej godności, odzwierciedlać ma suma przypisanych im punktów. Natomiast wysokość samego uposażenia stanowi iloczyn tak ustalonej liczby punktów oraz wartości kwotowej określanej periodycznie przez Konferencję Biskupów. Kwoty składające się na należne duchownemu uposażenie mogą natomiast pochodzić (i zwykle pochodzą) z różnych źródeł. Na pierwszym miejscu do przyczyniania się do zapewnienia duchownym należnego im uposażenia, zgodnie z precyzyjnie określonymi regułami, zobowiązane są kościelne jednostki organizacyjne, przy których pełnią oni posługę. W skład omawianego uposażenia wchodzą następnie wynagrodzenia należne duchownym ze względu na wykonywanie przez nich pracy na rzecz podmiotów niekościelnych oraz (jedynie w określonej części) świadczenia emerytalne przysługujące $\mathrm{z}$ racji wykonywania takiej pracy $\mathrm{w}$ przeszłości. Finansowa interwencja instytutów do spraw utrzymania duchowieństwa przewidziana jest natomiast wówczas, gdy kwoty uzyskane

54 Comitato per il sostentamento del clero, Circolare n. 11 (17.06.1986), https:/ / giuridico. chiesacattolica.it/circolari-del-comitato-per-gli-enti-e-i-beni-ecclesiastici/ (dostęp: 13.11.2018 r.). Zob. C. Redaelli, Il concreto funzionamento del sistema di sostentamento del clero in Italia, Quaderni di Diritto Ecclesiale 1989, nr 1, s. 23.

55 W ten sposób: N. Fiorita, Remunerazione..., s. 128.

56 Zwraca na to uwage P. Floris, La remunerazione del clero, w: Enti di culto e finanziamento delle confessioni religiose. L'esperienza di un ventennio (1985-2005), red. I. Bolgiani, Bologna 2007, s. 292. 
z poprzednio wymienionych źródeł nie osiągają wysokości uposażenia należnego określonemu duchownemu (i jedynie w zakresie koniecznym do osiągnięcia tej wysokości). Na tychże instytutach spoczywa również obowiązek regulowania za duchownych należnych zobowiązań podatkowych i odprowadzania za nich składek ubezpieczeniowych ${ }^{57}$.

\section{Działania pastoralne Konferencji Biskupów Włoch}

Realizowana reforma wiązała się z szeregiem różnorodnych obaw i zagrożeń. Najważniejszym z nich było niebezpieczeństwo zbyt małych wpływów z ustanowionego wówczas mechanizmu asygnaty podatkowej i darowizn odliczanych od podstawy opodatkowania. Rezygnując bowiem z (ograniczającego niezależność i niesprawiedliwego, ale zapewniającego względne bezpieczeństwo) systemu wypłacanych przez państwo duchownym dodatków uzupełniających, powierzono sprawę utrzymania Kościoła w całości „wolnej woli wierzących obywateli” ${ }^{58}$. Niemałe znaczenie posiadało również ryzyko niedostatecznego zrozumienia potrzeby dokonania zmian przez tytulariuszy beneficjów, których pozbawiono należnych im uprzednio praw w imię lepszej realizacji zasady sprawiedliwości wobec wszystkich duchownych. Obawy te nie były obce włoskim biskupom. Wymownie świadczy o tym treść dwóch dokumentów, których celem było publiczne wyjaśnienie motywów podjęcia reformy i uświadomienie wiernym zadań ciążących na nich zgodnie z naturą Kościoła i wyraźnymi przepisami KPK.

Pierwszym z zasygnalizowanych dokumentów jest list skierowany w styczniu 1987 r. przez Prezydium Konferencji Biskupów do wszystkich włoskich kapłanów. W wystąpieniu tym nie zabrakło wyrazów świadomości niezadowolenia niektórych środowisk $\mathrm{z}$ podjętych decyzji oraz

57 Zob. N. Fiorita, Remunerazione..., s. 121-130; P. Stanisz, Konkordatowa reforma..., s. 43-44.

58 Jak pisze Giorgio Feliciani, „była to odwaga, która w opinii wielu ocierała się o zuchwałość, ponieważ zupełnie brakowało wiarygodnych i umotywowanych prognoz, które by dotyczyły możliwych rezultatów tak istotnej decyzji”. Zob. G. Feliciani, 30 lat dobra wspólnego. Referat wygłoszony na Krajowym Sympozjum Delegatów Diecezjalnych "Sovvenire" nt. Partecipazione e corresponsabilità dei fedeli a sostegno di una Chiesa in uscita, Venezia Mestre, 7-9 maja 2018 r., Studia z Prawa Wyznaniowego 2018, t. 21, s. 395. 
związanych z tym wyjaśnień ${ }^{59}$. Szczególną wagę posiada jednak kilkudziesięciostronicowy dokument przyjęty w trakcie obrad XXX Zgromadzenia Plenarnego Konferencji Biskupów Włoch (24-27 października 1988 r.), który został skierowany do całego włoskiego Kościoła. Wychodząc od teologicznych i prawnokanonicznych racji przeprowadzenia realizowanej już reformy, podkreślono w nim współodpowiedzialność wszystkich wiernych za stworzenie warunków skutecznej realizacji misji Kościoła oraz zaapelowano o należytą troskę o zaspokojenie jego koniecznych potrzeb z wykorzystaniem form przewidzianych w przepisach przyjętych w konsekwencji zawarcia Konkordatu z 1984 r. ${ }^{60}$ Trudno mieć wątpliwości, że znacząco zwiększono $\mathrm{w}$ ten sposób szanse na pozytywne rezultaty reformy podjętej w konsekwencji zawarcia włoskiego Konkordatu z 1984 r., uwzględniając ponadto prawdziwą naturę Kościoła jako wspólnoty.

\section{Zakończenie}

Reforma systemu finansowania Kościoła katolickiego i utrzymania jego duchowieństwa, podjęta we Włoszech zgodnie z Konkordatem z 1984 r., była zadaniem o wyjątkowo dużym stopniu złożoności. Od jej projektodawców wymagało to nie tylko głębokiego przekonania o konieczności dokonania zmian, ale i czytelnej wizji trybu i procedur, które powinny znaleźć zastosowanie. Należało bowiem nie tylko doprowadzić do skomplikowanego porozumienia między przedstawicielami Państwa i Kościoła, ale i wyprowadzić konsekwencje z niezależności Kościoła w sprawach należących do jego własnego zakresu działania. Natomiast

59 Zob. Lettera informativa della Presidenza CEI ai sacerdoti d'Italia, NCEI 1987, nr 1, s. 4-10.

60 Zob. Sovvenire alle necessità della Chiesa. Corresponsabilità e partecipazione dei fedeli. Documento dell'Episcopato italiano, NCEI 1988, nr 7, s. 159-186. Różnego rodzaju dokumentów wyjaśniających szczegóły i konsekwencje przeprowadzonej reformy nie brakowało też na poziomie diecezjalnym. Odnosząc się przykładowo do Archidiecezji Mediolańskiej, należy zwrócić uwagę w szczególności na dwa okólniki wydane przez ks. bpa Renato Conti jako wikariusza generalnego w dniu 21 grudnia 1988 r.: Circolare ai parroci oraz Circolare ai responsabili degli enti diocesani, w: Il sostentamento del clero. Documentazione e quesiti. Strumento di lavoro per $i$ sacerdoti e $i$ Consigli pastorali e per gli affari economici delle Parrocchie, Milano 1989, s. 49-52 oraz 53-55. Na szczególną uwagę zasługują także zawarte w tej samej publikacji obszerne wyjaśnienia i odpowiedzi na stawiane przez duchownych pytania (s. 65-108). 
po stronie kościelnej konieczne było obranie drogi pozwalającej na podjęcie w krótkim czasie poważnych i licznych decyzji, które musiały posiadać odpowiednią legitymację i uzyskać zrozumienie duchowieństwa i wiernych świeckich. Wymagało to z jednej strony należytego poszanowania uprawnień poszczególnych biskupów i Zgromadzenia Plenarnego Konferencji Biskupów, a z drugiej wymuszało odwoływanie się niekiedy do reguł nieznajdujących czytelnego oparcia w normach KPK i ustanawianych ad hoc. Istotne znaczenie posiadało również niezaniedbywanie obowiązku wyjaśnienia motywów podejmowanych decyzji wszystkim tym, których miały one dotyczyć. Przeprowadzona analiza pozwala na stwierdzenie, że $\mathrm{w}$ trakcie realizacji omawianej reformy wszystkie wchodzące $\mathrm{w}$ grę racje udało się odpowiednio wyważyć. Dzięki temu rozwiązania zastosowane we Włoszech mogą stanowić użyteczny punkt odniesienia przy podejmowaniu podobnych procesów $\mathrm{w}$ innych państwach.

\section{Bibliografia}

Berlingò S., Fonti del diritto ecclesiastico, w: S. Berlingò, G. Casuscelli, S. Domianello, Le fonti e i principi del diritto ecclesiastico, Torino 2000.

Consorti P., La remunerazione del clero. Dal sistema beneficiale agli istituti per il sostentamento, Torino 2000.

Dalla Torre G., I tempi e le fasi di una lunga trattativa, w: I nuovi accordi concordatari tra Chiesa e Stato in Italia, Bologna-Roma 1985.

Dalla Torre G., La revisione del Concordato lateranense. Una vicenda lunga quarant'anni, Iustitia 2004, nr 2-3.

Feliciani G., Gli Istituti per il sostentamento del clero nella nuova normativa della CEI, Aggiornamenti Sociali 1985, nr 11.

Feliciani G., Il nuovo sistema di sostentamento del clero. Profili canonistici della legge 20.5.1985, n. 222, Aggiornamenti Sociali 1990, nr 1.

Feliciani G., Finansowanie instytucji kościelnych i utrzymanie duchowieństwa. Doświadczenia włoskie, w: Systemy finansowania instytucji kościelnych w Europie. Materiały Międzynarodowej Konferencji. Sandomierz 13-14 września 1999 r., red. J. Krukowski, Lublin 2000.

Feliciani G., L'Applicazione della legge 20 maggio 1985, n. 222. Gli esiti di una ricerca, Diritto Ecclesiastico 2006, cz. 1, z. 3-4.

Feliciani G., Introduzione, w: Enti di culto e finanziamento delle confessioni religiose. L'esperienza di un ventennio (1985-2005), red. I. Bolgiani, Bologna 2007. 
Feliciani G., 30 lat dobra wspólnego. Referat wygłoszony na Krajowym Sympozjum Delegatów Diecezjalnych "Sovvenire" nt. Partecipazione e corresponsabilità dei fedeli a sostegno di una Chiesa in uscita, Venezia Mestre, 7-9 maja 2018 r., Studia z Prawa Wyznaniowego 2018, t. 21.

Ferrari S., Państwo i Kościót we Wtoszech, w: Państwo i Kościót w krajach Unii Europejskiej, red. G. Robbers, tłum. J. Łopatowska-Rynkowska, M. Rynkowski, Wrocław 2007. Finocchiaro F., Diritto ecclesiastico, Bologna 2015.

Fiorita N., Remunerazione e previdenza dei ministri di culto, Milano 2003.

Floris P., La remunerazione del clero, w: Enti di culto e finanziamento delle confessioni religiose. L'esperienza di un ventennio (1985-2005), red. I. Bolgiani, Bologna 2007.

Kaleta P., Prawne aspekty zarządzania dobrami kościelnymi, Lublin 2017.

Kantor R., Odpowiednie wynagrodzenie duchownych w Kodeksie Prawa Kanonicznego z 1983 r. Analiza kan. 281 § 1, Prawo Kanoniczne 2011, nr 3-4.

Krukowski J., Święci szafarze, czyli duchowni, w: Komentarz do Kodeksu Prawa Kanonicznego, red. J. Krukowski, t. 2/1, Poznań 2005.

Lewandowski P., Troska biskupa diecezjalnego o godziwe utrzymanie duchownych, Kościół i Prawo 2016, nr 1.

Lewandowski P., The fund for the suport of the clergy according to the 1983 Code of Canon Law, Biuletyn Stowarzyszenia Kanonistów Polskich 2019, nr 32.

Lynch J.E., The obligations and rights of clerics, w: New Commentary on the Code of Canon Law, red. J. P. Beal, J. A. Coriden, T. J. Green, New York, N.Y.-Mahwah, N.J. 2000.

Marcuzzi G., Il sostentamento del clero nella normativa codiciale latina, w: Il sostentamento del clero. Nella legislazione canonica e concordataria italiana, Città del Vaticano 1993.

Margiotta Broglio F., Riforma della legislazione concordataria sugli enti e sul patrimonio ecclesiastico: $i$ «principi» della Commissione paritetica Italia - S. Sede, Foro Italiano 1984, cz. 5.

Margiotta Broglio F., Il negoziato per la riforma del Concordato tra Governo e Parlamento, w: Concordato e Costituzione. Gli accordi del 1984 tra Italia e Santa Sede, red. S. Ferrari, Bologna 1985.

Misztal H., Stanisz P., Włoski model finansowania związków wyznaniowych, w: Pro bono Reipublicae. Księga Jubileuszowa Profesora Michała Pietrzaka, red. P. Borecki, A. Czohara, T.J. Zieliński, Warszawa 2009.

Redaelli C., Il concreto funzionamento del sistema di sostentamento del clero in Italia, Quaderni di Diritto Ecclesiale 1989, nr 1.

Sobczyk P., Konstytucyjna zasada konsensualnego określania stosunków między Rzecząpospolitą Polska a Kościołem katolickim, Warszawa 2013.

Stanisz P., Porozumienia w sprawie regulacji stosunków między państwem i niekatolickimi zwiazkami wyznaniowymi we włoskim porządku prawnym, Lublin 2007.

Stanisz P., Perspektywy zmiany systemu finansowania kościołów i innych związków wyznaniowych w Polsce, Studia z Prawa Wyznaniowego 2009, t. 12. 
Stanisz P., Sprawy majątkowe jako element stosunków między państwem a związkami wyznaniowymi, w: Finansowanie kościołów i innych związków wyznaniowych, red. P. Sobczyk, K. Warchałowski, Warszawa 2013.

Stanisz P., Konkordatowa reforma systemu finansowania Kościoła we Włoszech, Premislia Christiana 2014/2015, t. 16.

Vegas G., L'otto per mille a vent'anni dalla revisione del Concordato lateranense, Quaderni di Diritto e Politica Ecclesiastica 2004, nr 1.

Ventura M., Religion and Law in Italy, Alphen aan den Rijn 2013.

Walencik D., Finansowanie Kościoła katolickiego w Polsce w świetle art. 22 i 27 konkordatu oraz prac komisji konkordatowych - perspektywa zmian, w: Konkordat: ocena z perspektywy 15 lat obowiązywania, Kraków 2014.

\section{Streszczenie}

Funkcjonujący dziś we Włoszech system utrzymania katolickiego duchowieństwa, będący konsekwencją reformy zainicjowanej Układem modyfikującym Konkordat Laterański podpisanym w 1984 r., stanowi jedną z najpoważniejszych, pozytywnie zweryfikowanych przez upływ czasu prób realizacji kan. 1274 Kodeksu Prawa Kanonicznego z 1983 r. Na baczną uwagę zasługuje jednak nie tylko treść składających się nań rozwiązań, ale i przyjęty tryb ich opracowywania oraz uchwalania, co stanowi przedmiot niniejszego opracowania. Proces realizacji omawianej reformy stanowi bowiem inspirujący przykład lojalnego i efektywnego współdziałania władz państwowych i kościelnych w ustanawianiu przepisów mających znaczenie w obu porządkach prawnych (państwowym i kościelnym), wyraźnie dowartościowując przy tym rolę krajowej Konferencji Biskupów. Natomiast po stronie kościelnej szczególną uwagę zwracają decyzje stanowiące wyraz poszukiwania równowagi pomiędzy należytym poszanowaniem uprawnień poszczególnych biskupów diecezjalnych i Zgromadzenia Plenarnego tworzonej przez nich Konferencji oraz potrzebą sprawnego działania, wymuszającą niekiedy odwoływanie się do reguł nieznajdujących czytelnego oparcia w normach Kodeksu Prawa Kanonicznego i ustanawianych ad hoc. Istotne znaczenie posiadało również niezaniedbywanie obowiązku wyjaśnienia motywów decyzji podejmowanych przez władze kościelne wszystkim tym, których te decyzje miały dotyczyć. Przeprowadzona analiza pozwala na stwierdzenie, że $\mathrm{w}$ trakcie realizacji omawianej reformy wszystkie wchodzące w grę racje udało się odpowiednio wyważyć. Dzięki temu rozwiązania zastosowane we Włoszech mogą stanowić użyteczny punkt odniesienia przy podejmowaniu podobnych procesów w innych państwach.

Słowa kluczowe: utrzymanie duchowieństwa, finansowanie Kościoła, włoski Konkordat z 1984 r., Konferencja Biskupów 


\section{THE PROCESS OF REALIZATION OF THE REFORM OF THE ITALIAN SYSTEM OF REMUNERATION OF THE CLERGY ACCORDING TO THE CONCORDAT OF 1984}

\section{Sum mary}

The present Italian system of the remuneration of the Catholic clergy, which is the consequence of the reform initiated by the 1984 Agreement modifying the Lateran Concordat, constitutes one of the most important attempts to implement Can. $1274 \S 1$ of the Code of Canon Law of 1983. However, not only the solutions of which it consists, but also the procedure of elaborating and enacting these solutions - which is the subject of the present study - deserve careful attention. The process of the realisation of the reform under discussion appears to be an inspiring example of loyal and effective collaboration between the State and Church authorities in establishing norms that are valid in both legal orders, while expressly appreciating the role of the national Bishops' Conference. What is especially noteworthy on the part of the Church are the procedural decisions that result from seeking balance between the due respect for the rights of individual diocesan bishops and the Plenary Assembly of the Bishops' Conference on the one hand, and the need to act efficiently on the other (sometimes according to the rules established at hoc, with no apparent basis in the norms of the Code of Canon Law). The open explanation of the decisions made by the Church authorities to all interested subjects played an important role as well. The conducted analyses lead to the conclusion that all the factors mentioned above were adequately balanced. As a consequence, the solutions used in Italy can constitute a useful point of reference for similar processes undertaken in other countries.

Key words: remuneration of the clergy, Church financing, Italian Concordat of 1984, Bishops' Conference

\section{ПРОЦЕСС ПРОВЕДЕНИЯ РЕФОРМЫ ИТАЛЬЯНСКОЙ СИСТЕМЫ СОДЕРЖАНИЯ ДУХОВЕНСТВА В СООТВЕТСТВИИ С КОНКОРДАТОМ ОТ 1984 ГОДА}

\section{Резюме}

Система содержания католического духовенства, функционирующего сегодня в Италии, как следствие реформы, инициированной Договором, изменяющим Латеранский конкордат, подписанным в 1984 году, с течением времени можно признать одной из самых серьезных, позитивно проверенных попыток реализации кан. 1274 Кодекса канонического права от 1983 года. Не только содержание его решений заслуживает пристального 
внимания, но и принятый порядок их разработки и принятия, который является предметом настоящего исследования. Процесс реализации рассматриваемой реформы является вдохновляющим примером лояльного и эффективного сотрудничества государственных и церковных властей в установлении нормативных актов, относящихся к правовому порядку (как государственному, так и церковному), а также явно усиливает роль национальной Конференции епископов. С церковной стороны особое внимание уделяется решениям, которые являются выражением поиска баланса между должным уважением прав отдельных епархиальных епископов и Пленарного собрания Конференции, которую они создают, и необходимостью эффективной работы, иногда требующей ссылки на правила, которые не поддерживаются четко нормами Кодекса канонического права и установлены ad hoc. Также было важно не пренебрегать обязанностью объяснять причины решений, принятых церковными властями, всем тем, на кого эти решения должны были повлиять. Проведенный анализ позволяет сделать вывод, что в ходе реализации обсуждаемой реформы все существенные аргументы были должным образом сбалансированы. В результате решения, применяемые в Италии, могут быть полезной отправной точкой при проведении аналогичных процессов в других странах.

Ключевые слова: содержание духовенства, церковное финансирование, Итальянский конкордат от 1984 г., Конференция католических епископов 